extremely low return rate' of 'only' 6.4 per cent of great interest. This was their achievement despite 'considerable persistence'. There are many 'disappointed' amongst those treading the path of questionnaire-based research.

Trainee psychiatrists might be considered as being much closer to home than 'ballet and opera companies and symphony orchestras'. However, when we tried to get them to answer a questionnaire on their attitudes to, and training in psychotherapy, we could only raise 66 and 46.5 per cent response rates from the Irish Eastern ${ }^{1}$ and Northern ${ }^{2}$ Regions respectively. Replies from the other two Irish Regions were zero per cent and three trainees respectively. In a study dealing with medical practitioners' technical information $^{3}$ we received an overall return rate of 13.5 per cent ( 15.3 per cent of consultant psychiatrists, 11.3 per cent of trainee psychiatrists, and 13.7 per cent of general practitioners). Attempts to retrieve a greater number of completed questionnaires were met with frankly paranoid, aggressive and condescending remarks. One GP became so upset that he unintentionally sat in his kitchen sink! All of this occurred despite considerable reassurances of confidentiality.

We could enumerate many more examples of the kind of experiences related by El-Sobky and O'Grady. Suffice it to say that our response rates have varied from nil from civil servants asked about grief* to 100 per cent from a captive audience in a large tyre-manufacturing plant. ${ }^{5}$

The last survey ${ }^{5}$ was a pilot project and we unfortu- nately found ourselves devoid of the necessary funds to pursue the matter. These tribulations are the stuff of research, and the would-be researcher should not be daunted if they raise their ugly heads during his or her endeavour. 'Suspicion and resistance to concepts of psychiatric ... research' are the prerogatives of no individual or organisation.

BRIAN O'SHEA Catherine McCollam BREDA SYNNOTT

Newcastle Hospital

Greystones, Co. Wicklow

\section{REFERENCES}

'O'Shea, B., Cahill, M. \& MCGennIs, A. (1983) Trainee psychiatrists: attitudes to psychotherapy and its training. Irish Journal of Psychotherapy, 2, 10-13.

${ }^{2}$ Cahill, M., O'Shea, B. \& McGennis, A. (1983) Trainee psychiatrists: attitudes to psychotherapy and its training in Northern Ireland. Irish Journal of Psychotherapy, 2, 75-77.

${ }^{3}$ O'Shea, B. M. \& McGennis, A. J. (1983) Prescribing psychotropics: Part 1. An analysis of technical information. Irish Medical Journal, 76, 135-137.

4 - O'Rourke, M. H., MeE, D. D. \& CanNon, A. (1982) Consensus of agreement between bereavement literature and helping agencies in Ireland. Irish Medical Journal, 75, 197-199.

5 - (1983) ECT: lay attitudes and experiences-a pilot study. Irish Medical Journal, 76, 40-43.

\title{
Squibb Travelling Fellowship
}

This Fellowship, valued $£ 5000$, is open to members of the College working in the United Kingdom or the Republic of Ireland who are of senior registrar or lecturer grade or equivalent, or are consultants within three years of their first consultant appointment.

The award is intended to cover expenses for travel abroad, to one or two centres, for a period of not less than three months, in pursuit of further study, research or clinical training relevant to the applicant's current interests. Applications should include a curriculum vitae; a state- ment of current interests and planned study abroad, with supporting statements from the proposed host centre and the names of two referees; and confirmation from the applicant's employing authority that study leave would be granted if the applicant was successful.

Applications should be sent by 30 April 1986 to the Dean of the College, who will be happy to answer any queries.

J. L. T. BIRLEY, Dean

\section{Reduced Subscriptions}

The International Journal of Psycho-Analysis and the International Review of Psycho-Analysis are offering subscriptions at a reduced rate to members of organisations wishing to subscribe through their societies as block subscribers. The reduced rate for block subscriptions is $£ 24.00$ for the Journal or Review and $£ \mathbf{4 4 . 0 0}$ for a joint subscrip- tion to both journals. A minimum of eight subscribers only is required; the journals are published in four parts and despatched in March, May, August and December. Those members wishing to subscribe to either or both of these reviews should write to Deborah Hart at the College.

\section{Telephone Answering Service}

The College switchboard has now been equipped with a telephone answering machine. This will operate between $6.0 \mathrm{pm}$ and $8.0 \mathrm{am}$ and at weekends. Messages may be left during these hours.

\section{Dr Anatoly Koryagin}

Dr Koryagin (Bulletin, December 1985, 9, 244) has recently been moved to a labour camp-his address for correspondence is: USSR 618810, Permskaya oblast, Chusovskoi raion, st. Vsesvyatskaya, uchr. Vs-389/35 (Bolnitsa). 